\title{
Menopause Rating Scale: Validation and Applicability in Nepalese Women
}

\author{
Gehanath Baral ${ }^{1}$ \\ 1Paropakar Maternity and Women's Hospital, Thapathali, Kathmandu, Nepal.
}

\section{ABSTRACT}

Background: Menopausal Rating Scale is one of the globally used tools to assess quality of life in menopause and
peri-menopause. The aim of this study is to validate the standard menopausal rating scale in Nepalese menopausal
women and to test menopausal symptoms during clinical consultation at hospital.
Methods: Cross sectional validation study at Paropakar Maternity and Women's Hospital, Thapathali, Kathmandu.
Five-step language translation of menopausal rating scale from English to Nepali, questionnaire clarity assessment with
gynecologists and Likert scale questionnaire based interview to the clients. Reliability and validity tests applied. Each
component of rating scale analyzed.
Results: Nepali version of menopausal rating scale developed. Acceptable level (Cronbach's Alpha = 0.77) of tools
reliability obtained. Barlett's test of sphericity was highly significant and Pearson correlation between variables
was significant. Average age of menarche was 15 years, and mean and modal value of menopause was 48 and 50
years respectively. First menopausal symptom was vasomotor flush in $62 \%$, one-forth didn't experience flush, half
experienced mild to moderate flush and rest one-fourth had severe to very severe form; $50 \%$ had significant sleep,
bladder and sexual dysfunction. Three-fourth had vaginal dryness and musculoskeletal problem. One-half had some
degree of mental dysfunction.
Conclusions: Nepali version of menopausal rating scale developed. Baseline menopausal parameters obtained.
Keywords: Applicability; menopause; rating scale; validation.

\section{INTRODUCTION}

Menopause is characterized by the vasomotor, urogenital, psychological and physical symptoms that appear gradually due to depletion and fluctuation in ovarian estrogen hormone..$^{1-9}$

National demographic data ${ }^{10}$ shows $24.3 \%$ of women above 40 years of age and menopausal women at Paropakar Maternity and Women's Hospital (PMWH) are around 5\% (unpublished data from out-patient record) but adequate work hasn't been carried out yet.

Menopausal Rating Scale (MRS) is internationally validated one of the quality of life (QoL) instruments in different languages, commenced since early 1990s in German language. ${ }^{11-16}$ Many symptoms in this scale have association in between them. ${ }^{17}$

The objectives of the study are: to create a Nepali version of MRS, assess climacteric symptoms and evaluate its use in clinical practice. This is required for the applicability for the socio-cultural adaptation. ${ }^{12}$ It helps us to compare severity of symptoms over time and to measure the treatment effect later on. ${ }^{18}$

\section{METHODS}

This is a cross sectional validation study performed at Paropakar Maternity and Women's Hospital (PMWH), Thapathali, Kathmandu. Postmenopausal aged women up to 65 years attending Gynaecology OPD were interviewed and examined. The criteria to exclude were: women with history of cancer in remission or under treatment currently; history of alcohol or drug abuse and any mental disability or undergoing treatment for psychiatric disorders; patient with surgical menopause; and women with premature ovarian failure or known genital malformations. Considering $5 \%$ of post-menopausal women coming to Gynaecology OPD daily at PMWH and

Correspondence: Gehanath Baral, Paropakar Maternity and Women's Hospital, Thapathali, Kathmandu, Nepal. Email: gehanath@gmail.com, Phone: +9779841228829. 
taking a-error of $5 \%$ with estimated allowable error of $10 \%$ the required minimum sample would be 19 by using Sample Size Calculator application. Any multiple of this size would be the sample size for this study and thus 57 cases were analyzed for the purpose of this study during 3 months from May to July 2018.

Data collected by questionnaire based interview to the clients administered by enumerators; questionnaire clarity with gynecologists; and five-step language translation. Clinical examination findings were recorded according to designated proforma.

The MRS scale is a valuable tool for assessing health related quality of life of women in the menopausal transition and it is used worldwide. It is standardized scale meeting psychometric norms. English version of MRS is used to validate in Nepali version (Chart-1). There are 11 questions and each symptom has five ordinal scale of rating menopausal symptoms by its severity. Severity is described into five levels as none (0), mild (1), moderate (2), severe (3) and very severe (4). ${ }^{14}$

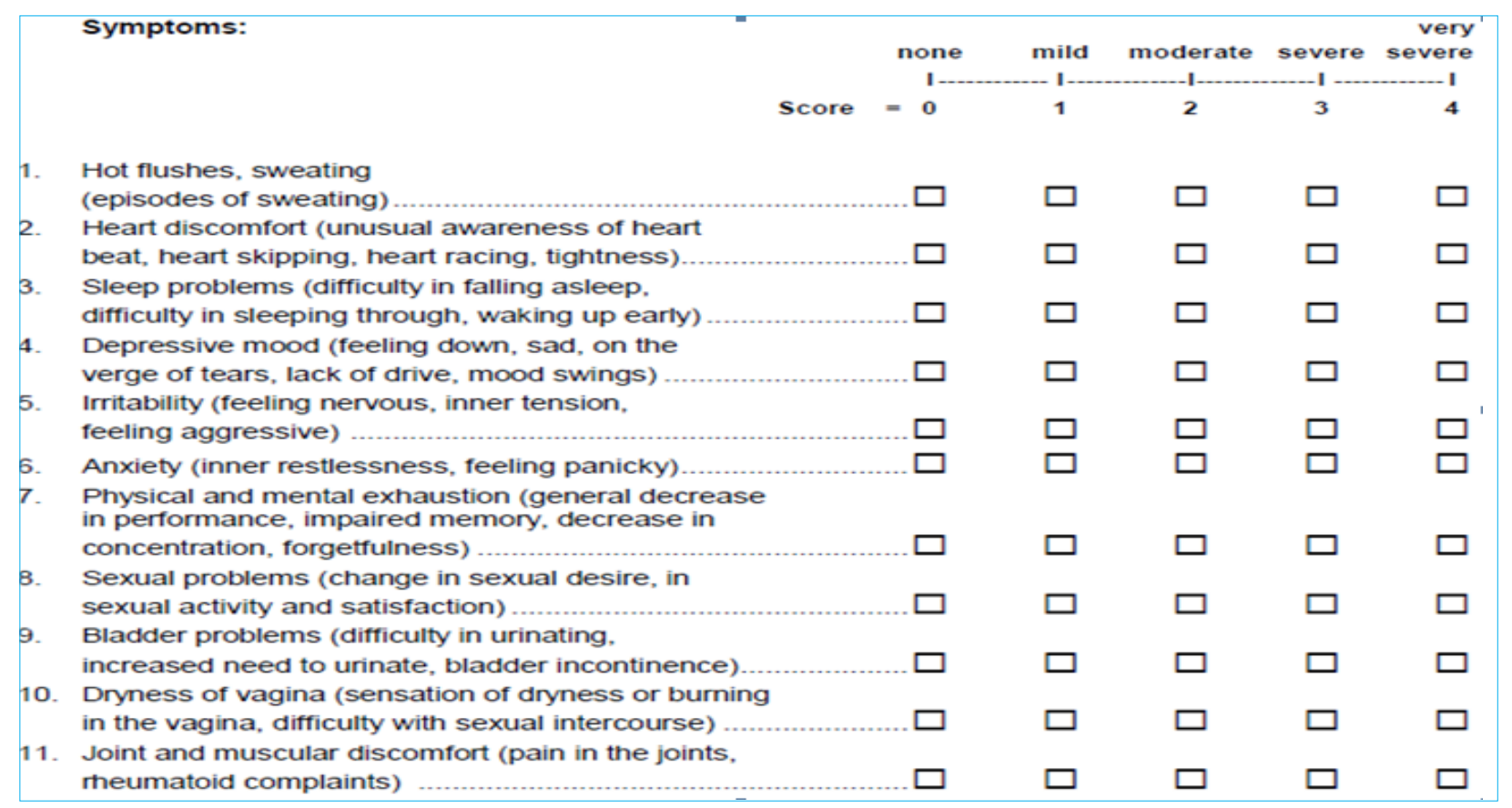

Chart 1. English version of Menopausal Rating Scale.

Five steps of the translation process adopted were: ${ }^{12}$ Forward translation of English version to Nepali version by at least two independent translators who are native Nepali speakers educationally trained in English medium; Correction of the wording of translation in Nepali; Backward translation by third translator who is native Nepali speaker, deals with Nepali speakers and educationally trained in English medium; Consensus meeting among the translators; and Cognitive debriefing (pretest with a few subjects the test has been designed for).

Test of research tool reliability (internal consistency) of the Nepali version of Menopause Rating Scale using Cronbach's alpha. Test of instrument's validity performed by means of confirmation factor analysis and Pearson's correlation coefficient. Assessment of the applicability performed by feedback from respondents, respondent's comprehension and questionnaire evaluation by healthcare professionals. ${ }^{11}$

This study is internationally validated questionnaire based interview without intervention and additional financial burden to the participants. Informed consent form was administered prior to the interview. There is no financial sponsorship yet. Research and ethical approval was taken from hospital IRC.

\section{RESULTS}

Nepali version of Menopausal Rating Scale was developed as "RAJANOBRITTA LAKSHAN MAAPAK" (Chart-2).

The average age of menopause amongst 57 cases was $48 \pm 5.2$ years (range: $35-58$, mean: 47.8 and median: 48 ) whereas the average age of menarche was $15 \pm 1.8$ years (range: 12-19, mean: 15.4 and median: 15) (Figure-1). 


\begin{tabular}{|c|c|c|c|c|c|c|}
\hline & गम्भिरता & बैन & थोरै & सध्यम & बही & धेरे बदी \\
\hline & गन्भिरताको स्तर & $\circ$ & $\mathrm{E}$ & $\mathrm{q}$ & 3 & $\mathbf{8}$ \\
\hline ? & घरि-घरि शरीर तातो हुने वा पसिना आऊेंने & $\square$ & $\square$ & $\square$ & $\square$ & $\square$ \\
\hline २ & $\begin{array}{l}\text { मुटुमा अप्ठेरो महशुस हुने (मुटुको चाल थाहा } \\
\text { पाउने, मूट्को ढुक्टुका बढ़ने वा बीच-बीचमा खुट्ने, } \\
\text { आत्त कास्सिए जस्तो हने) }\end{array}$ & $\square$ & $\square$ & $\square$ & $\square$ & $\square$ \\
\hline 3 & $\begin{array}{l}\text { निन्द्राको समस्या (निन्द्रा पर्न गाहो हुने, बिच- } \\
\text { बिचमा निन्द्रा खुल्ने, निन्द्रा छिटो ख़ल्ने) }\end{array}$ & $\square$ & $\square$ & $\square$ & $\square$ & $\square$ \\
\hline $\mathbf{8}$ & $\begin{array}{l}\text { उदासीनता (दुखा वा खिन्न हुने, रुन मन लाग्ने, } \\
\text { उत्साह नहुने, मुड परिबत्तन भइराख़े) }\end{array}$ & $\square$ & $\square$ & $\square$ & $\square$ & $\square$ \\
\hline 9 & झकेने, रीस उठ्ने, नर्भस हुने, आक्रमक अनुभव हुने & $\square$ & $\square$ & $\square$ & $\square$ & $\square$ \\
\hline$\varepsilon$ & $\begin{array}{l}\text { तनाव हुने (मनमा खटपटी हुने, आत्तिको अनुभव } \\
\text { हुने) }\end{array}$ & $\square$ & $\square$ & $\square$ & $\square$ & $\square$ \\
\hline b & $\begin{array}{l}\text { शारीरिक तथा मानसिक थकान (काम परा गर्न } \\
\text { गाहों पर्ने, सम्झना शाक्तमा गडबडी हुने, एकाग्रता } \\
\text { नहुने, कराहरु बिस्सेन) }\end{array}$ & $\square$ & $\square$ & $\square$ & $\square$ & $\square$ \\
\hline$<$ & $\begin{array}{l}\text { यौन समस्या (यौन रूची, यौन कार्य र सन्तुष्टीमा } \\
\text { परिबत्तन आऊँने) }\end{array}$ & $\square$ & $\square$ & $\square$ & $\square$ & $\square$ \\
\hline \& & $\begin{array}{l}\text { पिसाब संबन्धि समस्या (पिसाब फेर्न गाहो हुने, } \\
\text { छिटो-छिटो पिसाब फेन मन लाग्ने, पिसाब चुहिने) }\end{array}$ & $\square$ & $\square$ & $\square$ & $\square$ & $\square$ \\
\hline eo & $\begin{array}{l}\text { योन मार्गको सुख्यापन (योन मार्गमा सुख्यापन } \\
\text { वा पोलेको अनुभव हुने, यौन संबन्ध राख गाहो हुने) }\end{array}$ & $\square$ & $\square$ & $\square$ & $\square$ & $\square$ \\
\hline ee & $\begin{array}{l}\text { जोनी तथा मासु को दुखाइ वा अप्ठेरो महशुस हुने, } \\
\text { वाथ जस्तो समस्या हुने }\end{array}$ & $\square$ & $\square$ & $\square$ & $\square$ & $\square$ \\
\hline
\end{tabular}

Chart 2. Nepali version of Menopausal Rating Scale (रजोनिबृत्त लक्षण मापक)

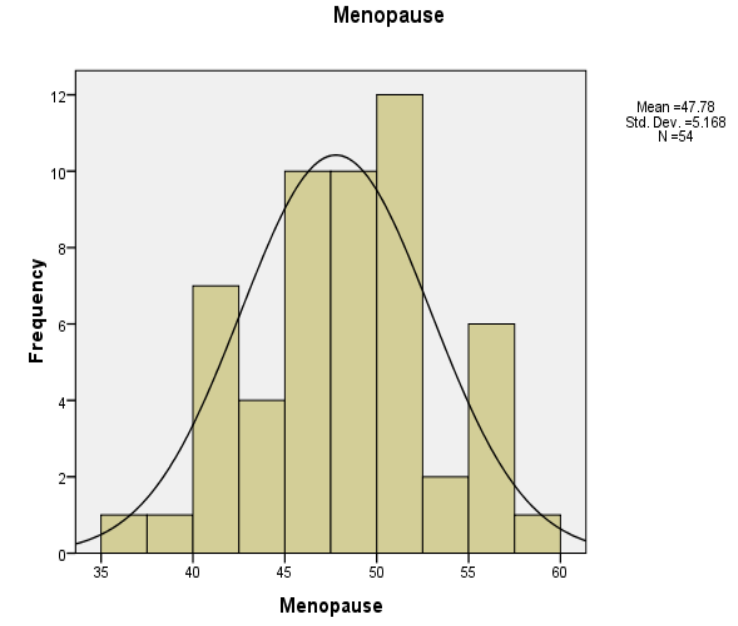

\section{Figure1. Distribution of menopausal age in years.}

Amongst 11 menopausal symptom categories either vasomotor flush or vaginal dryness and musculoskeletal problem were expressed by three-fourth of patients; and half of them had either mental dysfunction to some degree or sleep, bladder and sexual dysfunction. [Figure-2]

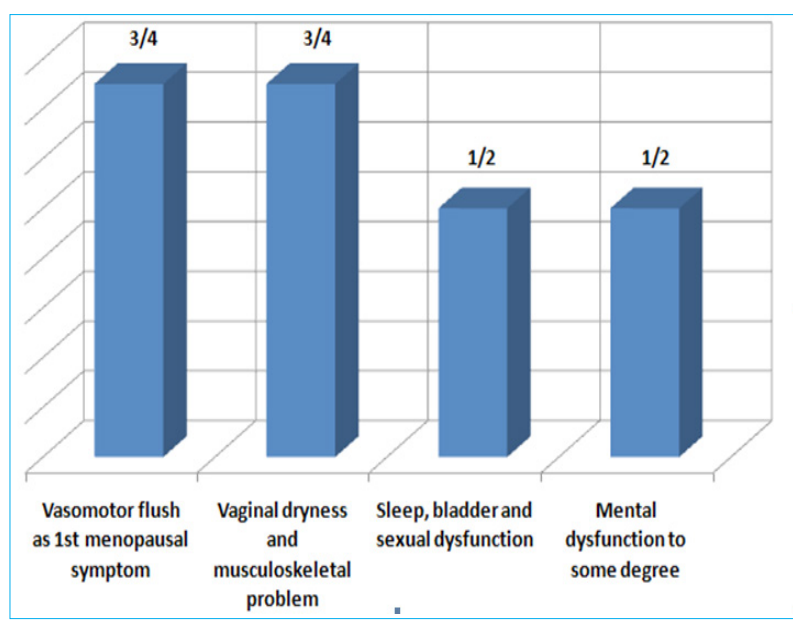

Figure 2. Common menopausal symptoms.

Out of first menopausal symptom, $60 \%$ had vasomotor flush and $36 \%$ didn't experience anything except cessation of menstruation (Figure 3). 


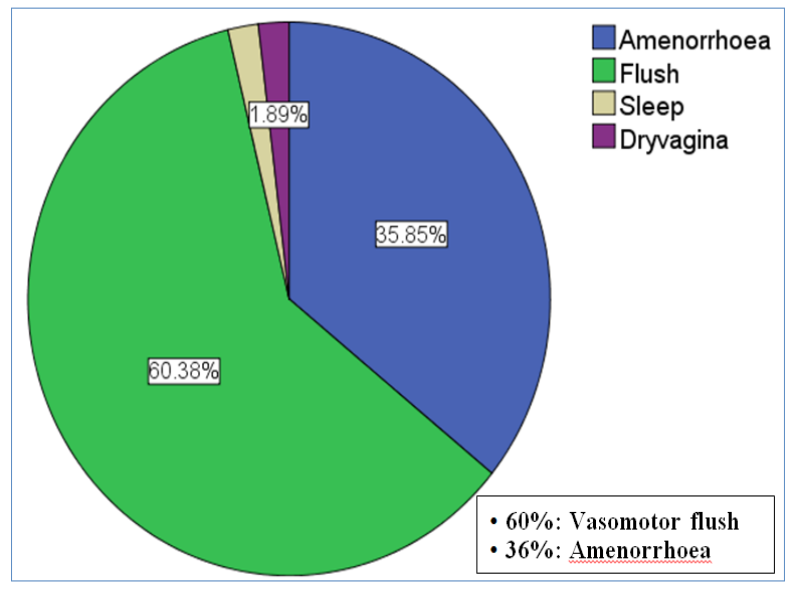

Figure 3. First menopausal symptoms.

By severity of flush, half of them had mild to moderate degree and one-forth had severe to very severe form (Figure 4).

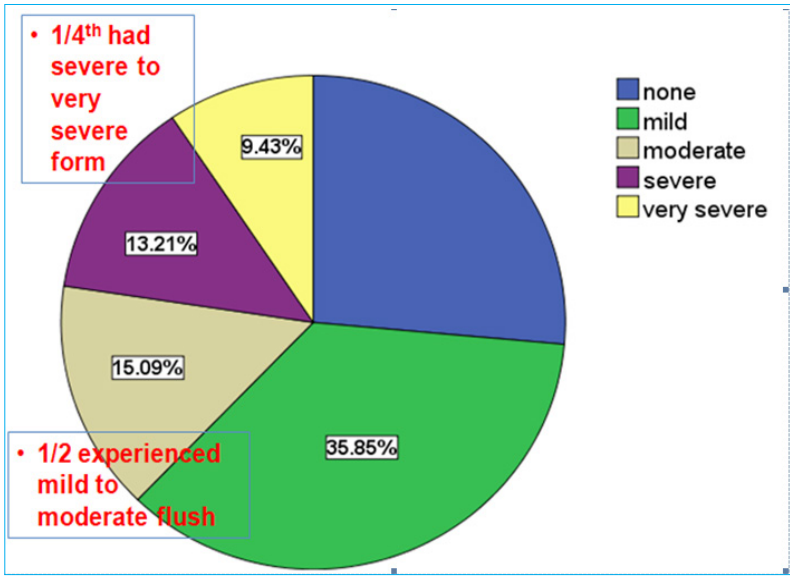

Figure 4. Severity of Vasomotor flush.

By frequency the common symptoms in decreasing order were muscle and joint discomfort, physical and mental exhaustion, vaginal dryness, bladder symptoms in more than $80 \%$; sleep problems, depressive mood and heart problems in $75-80 \%$; followed by hot flushes, sexual problems, irritability and anxiety in $70-75 \%$. All
11 components were present in $71-86 \%$ of cases without much difference in subscales. Urogenital symptoms appeared in severe degree in $15 \%$ of cases (Table 1 ).

\begin{tabular}{|c|c|c|c|}
\hline $\begin{array}{l}\text { Symptoms } \\
\text { Scale }\end{array}$ & Subscale & $\begin{array}{r}\text { All forms } \\
\text { (in \%) }\end{array}$ & $\begin{array}{r}\text { Severe } \\
\text { form (in } \\
\% \text { ) }\end{array}$ \\
\hline Hot flushes & Somatic & 74.5 & 12 \\
\hline $\begin{array}{l}\text { Heart } \\
\text { discomfort }\end{array}$ & Somatic & 77 & 9 \\
\hline $\begin{array}{l}\text { Sleep } \\
\text { problems }\end{array}$ & Somatic & 79 & 15 \\
\hline $\begin{array}{l}\text { Depressive } \\
\text { mood }\end{array}$ & Psychological & 79 & 6 \\
\hline Irritability & Psychological & 74 & 5 \\
\hline Anxiety & Psychological & 71 & 9 \\
\hline $\begin{array}{l}\text { Physical } \\
\text { and mental } \\
\text { exhaustion }\end{array}$ & Psychological & 86 & 12 \\
\hline $\begin{array}{l}\text { Sexual } \\
\text { problems }\end{array}$ & Urogenital & 74 & 10 \\
\hline $\begin{array}{l}\text { Bladder } \\
\text { problems }\end{array}$ & Urogenital & 83 & 16 \\
\hline $\begin{array}{l}\text { Dryness of } \\
\text { vagina }\end{array}$ & Urogenital & 85 & 19 \\
\hline $\begin{array}{l}\text { Joint and } \\
\text { muscular } \\
\text { discomfort }\end{array}$ & Somatic & 86 & 15 \\
\hline & Urogenital & 80.6 & 15 \\
\hline \multirow[t]{2}{*}{ Subscales } & Somatic & 79 & 13 \\
\hline & Psychological & 77.5 & 8 \\
\hline
\end{tabular}

Variable reliability test was done to see its internal consistency and it was at acceptable level of Cronbach alpha 0.77 . Pearson correlation between variables was found to be statistically significant at 0.05 or 0.01 (Table 2).

Table 2 .Pearson correlation between variables (significant at 0.05 or 0.01 ).

\begin{tabular}{|c|c|c|c|c|c|c|c|c|c|c|c|c|}
\hline SN & & 1 & 2 & 3 & 4 & 5 & 6 & 7 & 8 & 9 & 10 & 11 \\
\hline & Variables & $\begin{array}{l}\frac{\pi}{E} \\
\frac{\sqrt{y}}{J}\end{array}$ & $\begin{array}{l}\text { T } \\
\mathbb{D} \\
\stackrel{N}{7}\end{array}$ & $\begin{array}{l}\text { N } \\
\mathbb{D} \\
\text { D }\end{array}$ & 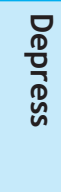 & $\begin{array}{l}\bar{\Xi} \\
\frac{\bar{d}}{\tilde{D}} \\
\frac{\sigma}{D}\end{array}$ & 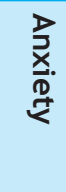 & 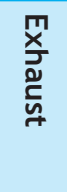 & $\begin{array}{l}\widetilde{\mathscr{D}} \\
\stackrel{x}{c} \\
\stackrel{0}{\varrho}\end{array}$ & 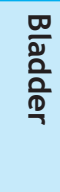 & 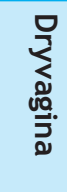 & 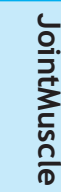 \\
\hline 1 & Flush & & .01 & & & & & & .05 & .05 & & .01 \\
\hline 2 & Heart & .01 & & & & & .05 & .05 & .01 & .01 & & \\
\hline 3 & Sleep & & & & .05 & & & & & & & \\
\hline
\end{tabular}


Menopause Rating Scale: Validation and Applicability in Nepalese Women

\begin{tabular}{|c|c|c|c|c|c|c|c|c|c|c|c|}
\hline 4 & Depress & & & .05 & & .01 & .01 & & & & \\
\hline 5 & Irritable & & & & .01 & & .01 & .05 & & & \\
\hline 6 & Anxiety & & .05 & & .01 & .01 & & .01 & & & .01 \\
\hline 7 & Exhaust & & .05 & & & .05 & .01 & & .01 & .05 & .05 \\
\hline 8 & Sexual & & .01 & & & & & .01 & & .01 & .05 \\
\hline 9 & Bladder & & .01 & & & & & .05 & .01 & & .01 \\
\hline 10 & Dryvagina & & & & & & .01 & .05 & .05 & .05 & \\
\hline 11 & Joint Muscle & .01 & .01 & & & & & & & & \\
\hline
\end{tabular}

The strength of relationship among variables was also highly significant by Bartlett's test of Sphericity (Chisquare $=161.742, d f=55, a=0.000)$. Evaluation of MRS questionnaire by healthcare professionals was fairly expressed as simple, comprehensible and administrable in clinical setting. Those were gynecologist, obstetrics and gynecology residents, pathology and lab medicine specialist, and psychiatrist.

\section{DISCUSSION}

The reliability test of Nepali version of MRS developed from this study carries statistically acceptable level of internal consistency as measured by Cronbach alpha of 0.77 in comparison to the preferable level in Czech Version with $0.87 .{ }^{11}$ It was found within the range of acceptable quality of 0.6 to 0.9 as determined in a methodological review. ${ }^{19}$

Theoretical construct validity (Face and content validity) was assured from the professionals. ${ }^{20-22}$ Criterion validity and concurrent validity was tested between each variable to another in a matrix by Pearson correlation that was found to be statistically significant at either 0.05 or $0.01 .{ }^{11}$ Third variable 'Sleep' was significantly correlated only with forth variable 'Depression' in this study. Researchers had found difficulty to clearly correlate this variable in their studies as well.

The strength of the relationship tested by Bartlett's Test of Sphericity among variables was highly significant by $p<0.000$ with chi-squared value of 162 and it is comparable to the Czech Version. It was supported by sample adequacy by 0.671 . Scale evaluation by health care professionals was better than in the Czech version.

Vasomotor flush was the main complaint in $60 \%$ cases as the first symptom; and the frequency of symptoms were comparable to the multinational study done by Blumel et al where the muscle and joint discomfort, physical and mental exhaustion were highly prevalent but by subscale urogenital symptoms appeared more in severe form in current study. ${ }^{23}$ The most common symptoms found namely joint and muscle discomfort and exhaustion were the same as in an Indian study. ${ }^{24}$

Average age of menopause was $48 \pm 5.2$ yrs (Range $=$ 35-58) which was comparable to a study done in India ${ }^{24}$ where the mean age of menopause was $48.9 \pm 3.2 \mathrm{yrs}$ (range $=45-52$ ); 48.5 and 49.38 yrs in two Pakistani studies. ${ }^{8,25}$

\section{CONCLUSIONS}

Nepali version of menopausal rating scale developed. Adequate level of tools reliability and validity obtained; so this scale points towards usefulness of the tool to measure the menopausal quality of life assessment.

\section{REFERENCES}

1. Hoffman BL, Schorge JO, Bradshaw KD, Halvorson LM, Schaffer JI, Corton MM. Williams gynecology. 3rd ed. McGraw Hill Education; 2016. P.471

2. Padubidri VG, Daftary SN. Howkins \& Bourne Shaw's Textbook of Gynaecology. 16th ed. Faridabad, Haryana: Thomson Press India Ltd; 2015.

3. Syed ASA, Siti RZ, Verna LKM. Assessment of menopausal symptoms using modiied menopausal rating scale among middle age women in Kuching, Sarawak, Malasysia. J Asia Pacific Family Med. 2010;9:1-6.

4. Chuni N, Sreeramareddy CT. Frequency of symptoms, dterminants of severe symptoms, validity of and cut-off score for Menopause Rating Scale (MRS) as a screening tool: A cross-sectional survey among midlife Nepalese women. BMC Womens Health. 2011;11:30.[DOI]

5. Marahatta R. Study of menopausal symptoms among peri and postmenopausal women attending NMCTH. Nepal Med Coll J. 2012;14(3):251-5.[Full Text Link]

6. Rajbhandari S, Amatya A, Giri K. Relation of ethnicity and menopausal symptoms in Nepal. 10.5005/jpjournals-10032-101. 
7. Shrestha NS, Pandey A. A Study of Menopausal Symptoms and its impact on lives of Nepalese perimenopausal and postmenopausal women. Journal of Kathmandu Medical College. 2017;6(19).[DOI]

8. Mazhar SB, Rasheed S. Menopause Rating Scale (MRS): A Simple Tool for Assessment of Climacteric Symptoms in Pakistani Women. Ann Pak Inst Med Sci. 2009;5(3):15861.[Full Text]

9. Santoro N, Epperson CN, Mathews SB. Menopausal Symptoms and Their Management. Endocrinol Metab Clin North Am. 2015;44(3):497-515.[DOI]

10. Central Bureau of Statistics. Statistical Year Book of Nepal - 2017. Kathmandu: Central Bureau of Statistics, National Planning Commission, Government of Nepal; 2018. 274p. URL cbs.gov.np/image/data/2018/Statistical\%20 Year\%20Book\%202017.pdf

11. Moravcová M, Mareš J, Ježek S. Menopause rating scale validation czech version specific instrument for assessing health-related quality of life in postmenopausal women. Ošetř́ovatelství a porodní asistence. 2014;5(1):36-45. [Full Text Link]

12. Heinemann LAJ, Potthoff P, Schneider HPG. International versions of the Menopause Rating Scale (MRS). Health and Quality of Life Outcomes. 2003;1:28. URL: http:/ / www.hqlo.com/content/1/1/28

13. Heinemann K, Assmann A, Möhner S, Schneider HPG, Heinemann LAJ. Reliabilität der Menopause-Rating-Skala (MRS). Zentralbl Gynakol. 2002;124(3):161-3.[Full Text]

14. Menopausal Rating Scale- English Version. Available at http: / / www.menopause-rating-scale.info/documents / MRS_English.pdf. Accessed: 28 April 2018.

15. Shin H, Shin HS. Measurement of Quality of Life in Menopausal Women: A Systematic Review. Western Journal of Nursing Research. 2012;34(4):475-503.

16. Nadeem F, Ruhi Khalid R. Development and Validation of Menopausal Symptoms Scale (MSS) for Pakistani Sample. Pakistan Journal of Social and Clinical Psychology. 2012;10(2):75-81.[Full Text Link]

17. Ziagham S, Sayhi M, Azimi N, Akbari M, Dehkordi ND, Bastami A. The Relationship Between Menopausal Symptoms, Menopausal Age and Body Mass Index With Depression in Menopausal Women of Ahvaz in 2012. Jundishapur J Chronic Dis Care. 2015;4(4):e30573.[Full Text Link]
18. Heinemann LAJ, DoMinh T, Strelow F, Gesbsch S, Schnitker J, Schneider HPG. The Menopause Rating Scale (MRS) as outcome measure for hormone treatment? A validation study. Health and Quality of Life Outcomes. 2004; 2:67.[Full Text Link]

19. Heinemann K, Ruebig A, Potthoff P, Schneider HPG, Strelow F, Heinemann LAJ, et al. The Menopause Rating Scale (MRS) scale: A methodological review. Health and Quality of Life Outcomes. 2004;2:45.[DOI]

20. Bolarinwa OA. Principles and methods of validity and reliability testing of questionnaires used in social and health science researches. Niger Postgrad Med J. 2015;22:195201.[Full Text]

21. Taherdoost H. Validity and Reliability of the Research Instrument; How to Test the Validation of a Questionnaire/ Survey in a Research. International Journal of Academic Research in Management. 2016;5(3). ISSN: 2296-1747. [DOI]

22. McDowell I. Measuring health: a guide to rating scales and questionnaires.3rd ed. New York: Oxford University Press, Inc; 2006.[Full Text Link]

23. Blumel JE, Chedraui P, Baron G, Belzares E, Bencosme A, Calle A, et al. Menopausal symptoms appear before the menopause and persist 5 years beyond: a detailed analysis of a multinational study. Climacteric. 2012;15:542-51. [DOI]

24. Pal A, Hande D, Khatri S. Assessment of menopausal symptoms in perimenopause and postmenopause women above 40 years in rural area. International J of Healthcare \& Biomedical Research. 2013;1(3):166-74. URL: www. ijhbr.com

25. Nisar N, Sohoo NA. Severity of Menopausal symptoms and the quality of life at different status of menopause: a community based survey from rural Sindh, Pakistan. International Journal of Collaborative Research on Internal Medicine \& Public Health. 2010;2(5):118-30. URL: http://www.iomcworld.com/ijcrimph/ 